\title{
Potensi Industri Produk Makanan Halal Di Kota Palu
}

\author{
Nurdin Nurdin ${ }^{1 *}$ Novia Novia ${ }^{2}$, Arif Rahman ${ }^{3}$, Ririn Suhada ${ }^{3}$ \\ ${ }^{1}$ Jurusan Perbankanb Syariah, Fakultas Ekonomi dan Bisnis Islam, IAIN Palu, email: nnurdin@iainpalu.c.id \\ ${ }^{2}$ Jurusan Ekonomi Syariah, Fakultas Ekonomi dan Bisnis Islam, IAIN Palu, email: noviaguroro1997@gmail.com, \\ ${ }^{3}$ Jurusan Ekonomi Syariah, Fakultas Ekonomi dan Bisnis Islam, IAIN Palu, email: arifrahman250719@gmail.com
}

ABSTRAK

Industri makanan yang bersertifikasi halal sudah semakin menjadi kebutuhan bagi masyarakat Muslim.Pemerintah diberbagai daerah semakin mendorong pengusaha untuk menngurus sertifikat halal bagi produk mereka. Kota Palu sebagai salah satu kota yang berpenduduk mayoritas Muslim dan juga memiliki jumlah usaha kecil yang paling banyak bergerak di bidang makanan dapat menjadi peluang peningkatan jumlah produk halal yang bersertifikasi halal. Namun saat ini belum ada penelitian yang melakukan seberapa besar potensi industri produk halal di kota Palu. Dengan menggunakan metode kualitatif dan pengumpulan data dilakukan melalui observasi, wawancara mendalam, dan bahan-bahan tertulis, dipereoleh hasil bahwa potensi industri makanan untuk tumbuh menjadi insdustri halal semakin tinggi.Sejumlah informan mengakui bahwa mereka sangat ingin mengurus sertifikat halal bagi produk mereka. Penelitian ini menyimpulkan bahwa kurangnya informasi yang diterima sedalam ini terkait proses pengurusan sertifikat halal merupakan masalah utama yang menghambat pengusaha mengurus sertifikat halal. Kedepan juga perlu ada penelitian lanjutan terhadap pengaruh masa berlaku sertifikat halal dengan minat mengurus sertifikat halal oleh industri kecil dibidang makanan karena ada indikasi pengusaha menginginkan masa berlaku serifikat yang lebih lama.
INFORMASI ARTIKEL

\author{
Katakunci: \\ Industri makanan,produk \\ halal, makanan \\ halal,potensi produk \\ halal, \\ Palu
}




\section{PENDAHULUAN}

Konsep produk atau makanan halal sekarang semakin menarik banyak pihak di seluruh dunia saat ini karena pengakuannya sebagai tolak ukur alternatif untuk keamanan, kebersihan dan jaminan kualitas dari apa yang masyarakat Muslim konsumsi atau minum setiap hari. Produk halal dipahami sebagai produk yang dihasilkan sesuai dengan persyaratan-persyaratan yang dapat diterima oleh masyarakat Muslim dan sesuai dengan syariat Islam(Ambali \& Bakar, 2014). Bagi konsumen Muslim, makanan dan minuman halal berarti bahwa produk tersebut telah memenuhi persyaratan yang ditetapkan oleh hukum Syariah, sedangkan untuk konsumen non-Muslim, produk tersebut melambangkan simbol produk kebersihan, kualitas dan keamanan ketika diproduksi secara ketat di bawah Jaminan Halal. Jadi produk halal tersebut bukan hanya dapat diterima oleh masyarakat Muslim saja tetapi juga oleh masyarakat nonmuslim.

Bagi masyarakat muslim, makanan menjadi satu hal penting mengingat makanan merupakan kebutuhan primer (pokok) sehari hari. Kebanyakan masyarakat (konsumen) mengutamakan cita rasa makanan dan kurang memperdulikan kehalalannya. Sejalan dengan ajaran syariah Islam, konsumen muslim menginginkan agar produk-produk yang dikonsumsinya terjamin kehalalan dan kebersihannya. Dalam ketentuan halal, haram, thayyib dan syubhat. Terkandung nilai spiritual yang mencerminkan keluhuran budi pekerti dan akhlak seseorang. Oleh karenanya, syariah islam menaruh perhatian yang sangat tinggi dalam menentukan makanan dan minuman halal, haram, maupun meragukan (subhat) (Ali, 2019).

Kota Palu yang penduduknya mayoritas Muslim juga menginginkan adanya produk-produk yang terserfikasi halal menurut ajaran syariat Islam. Namun kota palu juga dihuni oleh 16 persen penduduk non-muslim yang berasal dari berbagai daerah. Meskipun ada banyak masyarakat non-Muslim bukan berarti produk halal kurang diminati. Hasil penelitian yang dilakukan oleh Aziz \& Chok (2013) di Malaysia menunjukkan bahwa masyarakat non_Muslim juga menginginkan produk halal karena higienis dan sehat.

Ini berarti potensi produk halal dikota Palu dapat dikembangkan dengan lebih baik guna memenuhi kebutuhan masyarakat Muslim dalam menjalankan keyakinan mereka.Jumlah industri kecil yang bergerak dibidang makanan juga sangat banyak dikota Palu karena kanyanya sumber alam dibidang holtikultura.Dengan demikian peluang pengembangan usaha-usaha yang tersertifikasi halal juga semakin tinggi. 
Namun sampai saat ini belum ada penelitian yang mengkaji bagaimana potensi industri makanan halal di Kota Palu.Kurangnya data terkait potensi industri makanan halal dapat menghambat kebijakan pemerintah dalam mengembangkan berbagai produk halal dikota Palu.Untuk itu peneliti melakukan kajian terhadap potensi industri produk halal di Kota Palu untuk memberikan masukan kepada pemerintah dan masyarakat guna mendukung pengembangan industri produk makanan halal.

Tulisan ini akan disusun sebagai berikut; setelah bagian pendahuluan ini akan dibahas kajian pustaka yang mencakup konsep produk halal dan konsep halal dalam pandangan syariat Islam. Pada bagian ketiga akan disajikan metode yang digunakan dalam penelitian ini. Selanjutnya dalam bagian ke empat disajikan hasil penelitian dan pembahasan.Sedangkan kesimpulan dan keterbatasan penelitian disajikan pada bagian kelima, yang kemudian diikuti dengan rekomendasi di bagian akhir tulisan ini.

\section{TINJAUAN PUSTAKA}

\section{Konsep Produk halal}

Konsep Halal dalam penerapan kebijakan produk halal tidak hanya mencakup persyaratan Syariah, tetapi juga mencakup aspek kebersihan, sanitasi dan keselamatan yang berkelanjutan, dan juga membuat makanan halal yang mudah diterima oleh konsumen yang peduli tentang keamanan makanan dan gaya hidup sehat(Baharuddin, Kassim, Nordin, \& Buyong, 2015). Saat ini konsumen Muslimsemakin sadar akan keberadaan makanan halal . Kesadaran umat Muslim bukan hanya terkait bahwa suatu produk makanan adalah halal, tetapi mereka juga memililki kesadaran dan rasa keingintahuan yang mendalam terkait integritas status halal yang dihasilkan oleh sebuah produsen yang mencakup semua kegiatan yang terlibat di sepanjang rantai produksi dan pasokan sehingga berbagai produk yang mereka beli benar-benar halal (Zulfakar, Anuar, \& Talib, 2014).

Proses menuju halal bisa saja dimulai dari persiapan awal sampai akhir, misalnya produk daging halal proses persiapannya bisa saja dimulai dari pemotongan(Bonne \& Verbeke, 2008; Nakyinsige, Man, \& Sazili, 2012), yang kemudian dilanjutkan saat pengepakan (halal packaging) (Talib \& Johan, 2012), selanjutnya proses pengiriman juga dilakukan secara baik (halal logistic)(Jaafar, Endut, Faisol, \& Omar, 2011; Kamaruddin, Iberahim, \& Shabudin, 2012). Masalah kebutuhan akan layanan pengiriman halal (halal logistic) saat ini sudah semakin meningkatkarena tuntutan segmen pasar internasional terhadap produk halal. Proses pengiriman suatu produk halal 
seharusnya dilakukan tidak dengan cara mencampuradukkan dengan produk non halal. Kalaupun dilakukan pengiriman secara bersamaan maka perlu ada perlakukan khusus terhadap produk makanana halal agar tidak bercampur dengan produk nonhalal.

Namum, seiring dengan perkembangan waktu dan peningkatan kesadaran masyarakat Muslim terhadap kebutuhan produk halal, maka konsep halal juga telah merambah keberbagai bidang lain yang bukan hanya berupa produk yang bisa disentuh (tangible produk) tapi juga sudah masuk pada aspek jasa, misalnya wisata halal (halal tourism) (Battour \& Ismail, 2016; El-Gohary, 2016; Mohsin, Ramli, \& Alkhulayfi, 2016; Samori, Md Salleh, \& Khalid, 2016). Akibatnya muncullah hotel syariah dan restorant halal (halal restaurant) (Marzuki, Hall, \& Ballantine, 2014; Zannierah Syed Marzuki, Hall, \& Ballantine, 2012).Dalam hal ini, hotel syariah menerapakan nilai-nilai syariah dalam memberi pelayanan kepada masyarakat, seperti tamu pria dan wanita yang belum menikah tidak boleh satu kamar.Kemudian untuk restaurant halal, para manajer restoran diharuskan memiliki pengetahuan tentang syarat-syarat makanan halal menurut hukum Islam.

Dengan demikian konsep halal dalam tulisan ini bisa disimpulkan sebagai produk atau jasa yang persiapan, penyediaannya, dan distribusinya dilakukan menurut prinsipprinsip syariah yang berlaku dalam Islam. Dengan kata lain para produsen baik produk maupun jasa selalu mengacu pada nilai-nilai syariah Islam dalam menghasilkan dan menjual produk dan jasa mereka kepada masyarakat Muslim. Dengan demikian masyarakat Muslim dapat menerapakan keyakinan mereka dalam mendapatkan berbagai produk dan jasa dalam dunia perdagangan.

Produk Makanan Halal Dalam Konsep Syariah

Food Industry atau industry makanan adalah industri yang mencakup pengolahan produk pertanian, perkebunan, dan perikanan menjadi makanan dan juga mencakup produk setengah jadi yag tidak secara langsung menjadi produk makanan (Bigliardi \& Galati, 2013; Bremner, 2000; Hutkins et al., 2016). Industri makanan dewasa ini telah menjadi salah satu industry yang berkembang dengan pesat dewasa ini. Proses melahirkan produk makanan halal bukan hanya mulai dari sumber makanan itu berasal tetapi juga mencakup proses pengepakan, ditribusi, pengolahan sampai pada penyajian.

Halal secara bahasa, menurut sebagian pendapat, berasal dari akar kata الحل yang artinya (الإباحة) artinya sesuatu yang dibolehkan menurut syariat. Aljurjani 
menulis, kata halal berasal dari kata الحل yang berarti “terbuka" (الإباحة). Secara istilah, berarti setiap ketidak dikenakan sanksi penggunaannya atau sesuatu perbuatan yang dibebaskan syariat untuk dilakukan (Ali, 2019). Dalam Al-Qur'an Surah Al-A'raf [7]: 157. Allah berfirman : "Dan (Allah) menghalalkan bagi mereka segala yang baik dan mengharamkan bagi mereka segala yang buruk.

Pentingnya pencantuman label halal terhadap makanan menjadi garansi dalam konsumen untuk memilih makanan yang akan dikonsumsi, khususnya muslim. Seperti yg terdapat pada Al-qur'an Surah AlBaqarah [2]:168.

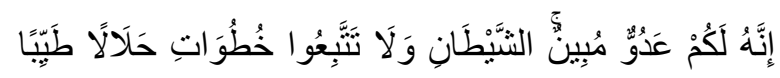



Artinya:

“Wahai manusia!Makanlah dari (makanan) yang halal dan baik yang terdapat di bumi dan janganlah kamu mengikuti langkahlangkah setan.Sungguh, setan itu musuh yang nyata bagimu." (QS.AlBaqarah:[2]:168).

Ditengah masyarakat yang cerdas dan selektif, sertifikasi halal menjadi keharusan. Permasalahannya kemudian, masih banyak pengusaha, terutama dari kalangan usaha kecil menengah yang belum memahami prosedur pengurusan maupun arti sertifikasi halal.
Jadi dapat ditarik kesimpulan Industry Halal Food adalah suatu kegiatan pengelolaan usaha yakni memproduksi, membuat, atau menghasilkan barangbarangberdasarkan prinsip syariah yang mengutamakan kehalalan suatu produk atau makanan, serta mendapatkan sertifikasi halal dari LP POM MUI sebagai suatu tanda bukti bahwa produk yang diperjual belikan telah memenuhi syarat kehalalan yang ditetapkan oleh Fatwa MUI.

\section{METODE PENELITIAN}

Penelitian ini menggunakan pendekatan kualitatif (Creswell, 1998; Yin, 2011) yang memungkinkan peneliti berinteraksi langsung dengan objek penelitian dilapangan. Data penelitian ini di kumpul dengan mengunakan tiga strategy yaitu observasi, wawancara mendalam, dan bahan-bahan tertulis atau dokumen (Miles \& Huberman, 1994; Yin, 2011). Observasi dilakukan untuk melihat secara langsung industri yang menghasilkan produk halal dikota Palu. Sedangkan wawancara mendalam (In-depth interview) (Minichiello, Aroni, Timewell, \& Alexander, 1990) dilakukan dengan tokoh MUI dan juga para pelaku industri halal terkait proses sertifikasi halal dan manfaatnya bagi para pelaku. Dalam penelitian ini peneliti mewawancarai dua tokoh MUI yang bertanggung jawab terhadap proses sertifikasi halal. Kemudian 
peneliti juga mewawancari 5 pelaku Industri halal yang telah mendapat sertifikat halal, dan 5 pelaku industri yang belum mendapat sertifikat halal tetapi ingin mendapatkannya. Kemudian peneliti juga mengumpul data melalui analisis sejumlah dokumen yang ada di kantor MUI kota Palu yang antara lain laporan jumlah sertifikat halal yang sudah diterbitkan dan proses penerbitan sertifikat halal.

Data hasil wawancara di olah dengan menggunakan pendekatan tematik analisis yang dimulai dari open koding, axial koding, sampai merumuskan hasil (Kendall, 1999; Strauss \& Corbin, 1998). Hasil observasi, wawancara, dan analisa dokumen direduksi terlebih dahulu dalam sebuah tabel matrix (Miles \& Huberman, 1994) yang kemudian setiap kutipan (quotes) dari tabel tersebut dimasukkan kedalam bagian pembahasan penelitian ini.

\section{HASIL DAN PEMBAHASAN}

\section{Data Industri Produk Halal di Kota Palu}

Makanan yang halal menjadi syarat utama terhadap makanan yang dikonsumsi oleh konsumen yang beragama islam. Berdasarkan data BPS Tahun 2015 penduduk kota palu sebesar 368.100 yang didominasi oleh penduduk muslim sebesar $84,06 \%$. Hal ini menandakan besarnya potensi dalam pengembangan industri halal food di Kota Paluserta perlunya peningkatan kesadaran terhadap konsumsi di sektor industri halal food. Jumlah penduduk kota Palu menurut agama dapat dilihat pada tabel 1 berikut ini:

Tabel 1. Penduduk kota Palu 5 tahun terakhir

\begin{tabular}{|l|r|r|r|r|r|}
\hline \multicolumn{6}{|c|}{$\begin{array}{c}\text { Persentase Penduduk Palu Menurut } \\
\text { Agama yang Dianut, 2013-2017 }\end{array}$} \\
\cline { 2 - 7 } Agama & \multicolumn{5}{c|}{ Tahun } \\
\hline \multicolumn{1}{|c|}{$(1)$} & $(2)$ & $(3)$ & $(4)$ & $(5)$ & $(6)$ \\
\hline Islam & 80,05 & 85,21 & 89,33 & 80,67 & 84,06 \\
\hline Kristen Protestan & 12,68 & 9,62 & 7,85 & 9,84 & 8,16 \\
\hline Kristen Katholik & 2,48 & 2,64 & 1,4 & 2,68 & 2,23 \\
\hline Hindu & 2,42 & 0 & 1,02 & 2,44 & 2 \\
\hline Budha & 2,37 & 2,53 & 0,4 & 4,37 & 3,55 \\
\hline Jumlah/Total & 100 & 100 & 100 & 100 & 100 \\
\hline
\end{tabular}

Sumber: Kandepag kota Palu, 2018

Industri produk halal baik dari Usaha Mikro, Kecil, dan Menengah tersebar hampir di setiap sudut Kota Palu.Data ini menandakan besarnya potensi dalam mengembangkan industri halal food tersebut.Industri tersebut mencakup industri makanan, seperti makanan yang bersumber dari coklat atau kakao, bawang goreng, ikan, dan berbagai produk lainnya yang sudah menembus pasar lokal, nasional dan bahkan pasar internasiona.Namun industri produk halal yang ada dikota Palu bukan hanya makanan tetapi juga jasa halal.Namun sebagian besar industri yang menghasilkan 
berbagai produk tersebut belum memiliki sertifikat halal. Menurut data satistik, saat ini ada 267 usaha kecil dikota Palu yang bergerak dibidang produk makanan (BPSSulawesi-Tengah, 2018). Disamping itu juga terdapat sejumlah usaha yang bergerak dibidang jasa, namum yang sudah bersertifikat masih kecil jumlahnya. Data industri yang sudah mendapat sertifikat halal menurut data dari LPPOM MUI Kota Palu adalah sebagai berikut:

Tabel 2. Industri Kecil yang sudah besertifikat halal di kota Palu

\begin{tabular}{|l|l|l|l|}
\hline No & Jenis Produk & Tahun 2017 & Tahun 2018 \\
\hline 1 & Makanan Ringan & 25 & 10 \\
\hline 2 & Produk Herbal & 3 & 1 \\
\hline 3 & Jasa pemotogan hewan & 1 & - \\
\hline 4 & Catering & 1 & - \\
\hline 5 & Minuman & 1 & - \\
\hline 6 & Café & 1 & - \\
\hline 7 & Batu Mulia & - & 1 \\
\hline
\end{tabular}

Sumber: Majelis Ulama Indonesia Kota Palu, 2018

Data pada tabel 2 menunjukkan perbandingan jumlah industri kecil yang sudah mendapatkan sertifikat halal dengan yang belum masih berbeda jauh.Sampai dengan tahun 2018 baru 44 industri kecil yang sudah mendaftarkan produknya untuk mendapatkan sertifikat halal.Ini berarti baru sekitar $16 \%$ dari industri kecil yang sudah mendapatkan sertifikat halal untuk produk mereka.Dari jumlah tersebut sebagian besar sertfikat halal diberikan kepada produk makanan, sebagian kecil lainnya diberikan kepada produk herbal, jasa pemotongan hewan, café, dan catering.Sedangkan untuk hotel belum ada yang mendaftarkan hotel mereka untuk mendapatkan sertifikat halal.

Data pada tabel di atas menunjukkan kecenderungan penurunan jumlah pengurusan sertifikasi halal selama tahun 2018.Peneliti menduga hal ini terjadi bisa saja dipengaruhi oleh musibah gempa, tsunami, dan liquifaksi tanggal 28 September 2018.Jadi penurunan bukan karena animo pihak industri produk makanan untuk mengurus sertifikat halal yang menurun, tetapi karena musibah tersebut.

\section{Peluang Pengambangan Produk Halal di Palu}

Sesuai data yang ada bahwa jumlah usaha kecil kota Palu yang bergerak dibidang produksi makanan ada sekitar 267 dan jumlah penduduk Muslim kota Palu sekitar $84 \%$ maka peluang pengembangan industri produk halal masih cukup besar. Produk halal merupakan kebutuhan masyarakat Muslim yang semakin meningkat karena kesadaran untuk menjalankan syariat Islam. Ketua Dewan Pakar Pengurus Besar Alkhairat dan sekaligus ketua MUI kota Palu mengatakan bahwa: 
Produk halal bagi umat Islam, yang mencakup aspek kehalalan produk yang dikonsumsi merupakan bagian dari ketetapan agama (syariat) yang harus dipatuhi. Dengan demikian, persoalan ini merupakan persoalan yang urgen bagi umat Islam karena terkait langsung dengan aspek syariat Islam (Zainal Abidin).

Pernyataan ketua MUI kota Palu ini menunjukkan bahwa usaha-usaha kecil yang bergerak dibidang produk makanan perlu memikirkan segera untuk mengurus sertifikasi halal guna merespon kebutuhan masyarakat Muslim kota Palu yang sekitar $84 \%$ tersebut. Namun menurut pengurus MUI Kota Palu lainnya mengatakan bahwa masalah ketidaktahuan seringkali membuat minimnya perusahaan memiliki kesadaran untuk mendaftarkan diri guna memperoleh sertifikat halal.Namun pihak MUI pada tahun-tahun berikutnya terus menggalakkan sosialisasi pentingnya pengurusan sertifikasi halal bagi produk-produk mereka. Sertifikat halal akan meningkatkan jumlah penjualan karena bertambahnya trust (keprcayaan) konsumen terhadap produk tersebut (Gunawan, 2018). Sedangkan manfaat sertifikat halal bagi produsen antara lain Memiliki Unique Selling Point (USP), Kesempatan Meraih Pasar Halal Global, Meningkatkan Kemampuan dalam Pemasaran di Pasar/Negara Muslim (Ramadhani, 2018).
Hasil wawancara dengan sejumlah pelaku industri produk makanan yang sudah mengurus sertifikat halal juga membuktikan bahwa sertifikat halal dapat membantu perkembangan bisnis mereka seperti disampaika oleh salah satu informan sebagai berikut:

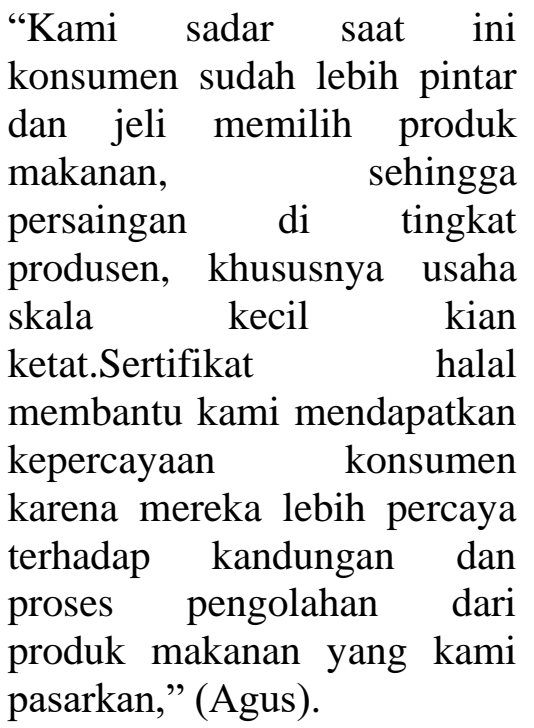

Jika saja MUI Kota Palu berhasil meyakinkan pelaku usaha kecil dibidang makanan untuk memiliki pandangan seperti informant di atas melalui berbagai kegiatan sosialisasi maka usaha - usaha kecil lainnya akan mengurus sertifikat halal. Pengaruh aktifitas sosialisasi yang baik terhadap minat mengurus sertifkasi halal sudah pernah diteliti sebelumnya seperti Pramitasari dan Fatmawati (Pramintasari \& Fatmawati, 2017), dimana semakin sering dan bagus kegiatan sosialisasi proses sertifikasi halal maka semakin meningkat jumlah usaha yang mengurus sertifikat halal bagi produk mereka. 
Meskipun jumlahpersentase produk usaha kecil menengah yang belum berlabel halal di kota Palu masih lebih banyak, bukan berarti mereka tidak mau mengurusnya. Mereka memiliki keinginan yang kuat untuk melakukan sertifikasi halal terhadap produk mereka.Namun selama ini mereka mengalami kesalahan persepsi terhadap prosedur pengurusan sertifikat halal. Misalnya salah seorang informan mengatakan seperti berikut ini:

Selama ini persepsi kami mengenai proses sertifikasi halal adalah rumit dan mahal. Saya dengar banyak dokumen yang diperlukan dan biaya juga mahal.Belum lagi waktu yang diperlukan juga lama sementara sertifikatnya hanya berlaku dua tahun saya dengar.Saya juga tidak tahu bagaimana memulai pengurusan tersebut, apakah langsung kekantor MUI atau harus kekantor lainnya dulu (Sudarmin).

Menurut pihak MUI, sebenarnya pengurusan sertifikat halal tidaklah rumit dan tidak memakan waktu lama jika semua dokumen telah lengkap. Namun penjelasan kepada pihak pengusaha yang kurang selama ini sehingga para pengusaha mempersepsikan proses pengurusan sertifikat halal menjadi sulit. Namun masa kadaluarsa sertifikat halal yang dua tahun bisa saja mempengaruhi minat pengusaha untuk mengurus sertifikat halal. Peneliti menduga masalah waktu kadaluarsa sertifikat bisa saja mempengaruhi minat tersebut karena sejumlah informan menginginkan sertifikat halal kadaluarsa lima tahun.

Pernyataan MUI bahwa pengurusan sertifikat halal tidaklah rumit dibenarkan oleh salah seorang pengusaha yang sudah mengurus sertifikat tersebut. Seorang informan pengusaha makanan olahan mengatakan seperti berikut ini:

"Saya tidak menemui
kesulitan dalam mendapatkan
sertifikasi $\begin{array}{r}\text { halal.saya } \\ \text { kemudahan }\end{array}$
memperoleh
karena usaha pembuatan
keripiknya saya berada di
bawah binaan dinas koperasi
pemerintah kota Palu.
Menjadi binaan dinas banyak
untungnya, selain kemudahan
dalam berpromosi, juga
gampang mengurus sertifikat
halal," (Tri Kismiati)

Pernyataan informan di atas, disamping membenarkan bahwa pengurusan sertifikat halal tidak sulit, juga memberi pelajaran kepada pengusaha lain yang merasa sulit untuk mengurus sertifikat halal untuk bergabung dengan kelompok binaan agar lebih mempermudah lagi proses pengurusan. Dengan demikian proses persiapan dokumen dan birokrasi pengurusan bisa diurus oleh Pembina kelompok.

Pihak MUI dalam sebuah kesempatan wawancar juga mengingatkan agar label halal yang tertera pada setiap produk 


\section{Jurnal IImu Ekonomi dan Bisnis Islam Vol.1 No. 1 Tahun 2019 \\ 10}

makanan, minuman, obat-obatan dan sebagainya itu jangan hanya sebatas simbol untuk meraih simpati konsumen Muslim tetapi juga harus diikutkan dengan pembuktian adanya sertifikat halal. Pernyataan informan dari MUI ini menekankan perlunya penerapan secara kongkrit label halal terhadap produk yang dihasilkan. Hasil penelitian yang dilakukan oleh (Darojatun, 2018) juga menemukan ada unsur gagah-gagahan dalam penggunaan sertifikat halal pada sebuah produk. Untuk itu perlu ada keseriusan pengusaha untuk mempraktekkan nilai-nilai halal kedalam proses produksi sebuah produk.

\section{KESIMPULAN DAN KETERBATASAN PENELITIAN}

Berdasarkan hasil penellitian dan pembahasan di atas, maka dapat kita lihat bahwa potensi industri produk halal dikota Palu tinggi.Jumlah industri kecil yang bergerak dibidang makanan cukup banyak.Meskipun yang telah mengurus sertifikat halal baru sekitar 16\%, tetapi hasil penelitian kami menunjukkan sejumlah pelaku usaha sangat ingin mengurus sertifikat halal. Cuma mereka kurang mendapatkan informasi yang tepat dan benar tentang proses pengurusan sertifikat halal.

Jumlah penduduk Muslim yang mayoritas (84\%) juga menjadi peluang bagi usaha kecil dibidang makanan untuk memasarkan produk mereka dengan menggunakan label halal yang resmi. Proses pengurusan yang tidak rumit dengan biaya yang rendah dan juga waktu yang tidak lama juga potensi lain untuk meningkatkan produk berlabel halal. Dengan demikian jumlah usaha kecil dibidang makanan yang memiliki sertifikat halal akan makin meningkat kedepan.

Penelitian ini memiliki keterbatasan karena jumlah informant yang diwawancara tidak mencakup semua pengusaha kecil karena keterbatasan waktu dan juga biaya. Namun penelitian ini telah dilakukan secara ilmiah dengan menggunakan metode yang tepat dan proses pemilihan informant yang tepat. Karena itu penelitian mendalam kami terhadap potensi industri produk halal dikota Palu berpotensi memberikan kontribusi berharga secara teoritis dan praktis kepada masyarakat (Myers, 2000).

\section{PENELITIAN KEDEPAN}

Hasil penelitian ini juga menunjukkan bahwa ada kecenderungan bahwa masa aktif sertifikat halal yang hanya dua tahun dapat menurunkan minat para pengusaha untuk mengurus sertifikat halal seperti ditemukan dalam wawancara dengan beberapa informan. Untuk membuktikan sejauh mana pengaruh masa berlaku sertifikat halal dengan minat mengurus sertifikat diperlukan ada peenilitan lain kedepan. 


\section{Jurnal IImu Ekonomi dan Bisnis Islam Vol.1 No. 1 Tahun 2019}

\section{1}

Rekomendasi

Industri makanan di Kota Palu memiliki potensi untuk dikembangkan sebagai industri yang halal agar sesuai syariat Islam, karena dilihat dari populasi masyarakat Kota Palu yang penduduknya mayoritas muslim, serta banyaknya Usaha Kecil dan Menengah (UKM) dibidang industri makanan yang tersebar di setiap sudut Kota Palu. Tetapi minimnya Industri makanan yang belum tersertifikasi halal

\section{DAFTAR PUSTAKA}

Ambali, A. R., \& Bakar, A. N. (2014). People's Awareness on Halal Foods and Products: Potential Issues for Policy-makers. Procedia - Social and Behavioral Sciences, 121, 3-25.

Aziz, Y. A., \& Chok, N. V. (2013). The Role of Halal Awareness, Halal Certification, and Marketing Components in Determining Halal Purchase Intention Among NonMuslims in Malaysia: A Structural Equation Modeling Approach. Journal of International Food \& Agribusiness Marketing, 25(1), 1-23.

Baharuddin, K., Kassim, N. A., Nordin, S. K., \& Buyong, S. Z. (2015). Understanding the Halal Concept and the Importance of Information on Halal Food Business Needed by Potential Malaysian Entrepreneurs. International Journal of Academic Research in Business and Social Sciences, 5(2), 170-180.

Battour, M., \& Ismail, M. N. (2016). Halal tourism: Concepts, practises, challenges and future. Tourism Management Perspectives, 19, 150154. masih menjadi suatu permasalahan dalam pengembangan industri makanan halal terutama karena minimnya pengetahuan pelaku usaha kecil yang belum memahami prosedur pengurusan maupun arti pentingnya sertifikasi halal. Untuk itu diperlukan adanya perhatian ekstra dari pemerintah dan pihak MUI kota Palu mengatasi masalah ini baik melalui sosialisasi maupun melalui penyederhanaan birokrasi.

Bigliardi, B., \& Galati, F. (2013). Innovation trends in the food industry: The case of functional foods. Trends in Food Science \& Technology, 31(2), 118129.

Bonne, K., \& Verbeke, W. (2008). Muslim consumer trust in halal meat status and control in Belgium. Meat Science, 79(1), 113-123.

BPS-Sulawesi-Tengah. (2018). Usaha Mikro Kecil. Retrieved 06 Maret 2019, from BPS-Sulawesi Tengah: https://palukota.bps.go.id/statictable/ 2016/08/02/178/jumlah-koperasidan-anggota-menurut-jenis-koperasi2011-2015.html

Bremner, H. A. (2000). Toward Practical Definitions of Quality for Food Science. Critical Reviews in Food Science and Nutrition, 40(1), 83-90.

Creswell, J. W. (1998). Qualitative Inquiry and Research Design: Choosing Among Five Traditions. London: Sage Publications.

Darojatun, R. (2018). Tren Produk Halal, Gaya Hidup Syar'i Dan Kesalehan Simbolik: Studi Tentang Muslim Kelas Menengah. Wardah, 19(135), 157. 


\section{Jurnal Ilmu Ekonomi dan Bisnis Islam Vol.1 No. 1 Tahun 2019}

\section{2}

El-Gohary, H. (2016). Halal tourism, is it really Halal? Tourism Management Perspectives, 19, 124-130.

Hutkins, R. W., Krumbeck, J. A., Bindels, L. B., Cani, P. D., Fahey, G., Goh, Y. J., et al. (2016). Prebiotics: why definitions matter. Current Opinion in Biotechnology, 37, 1-7.

Jaafar, H. S., Endut, I. R., Faisol, N., \& Omar, E. N. (2011). Innovation in logistics services - halal logistics (No. 34665). Kuala Lumpur: Universiti Teknologi MARA.

Kamaruddin, R., Iberahim, H., \& Shabudin, A. (2012). Willingness to Pay for Halal Logistics: The Lifestyle Choice. Procedia - Social and Behavioral Sciences, 50, 722-729.

Kendall, J. (1999). Axial Coding and the Grounded Theory Controversy. Western Journal of Nursing Research, 21(6), 743-757.

Marzuki, S. Z. S., Hall, C. M., \& Ballantine, P. W. (2014). Measurement of Restaurant Manager Expectations toward Halal Certification Using Factor and Cluster Analysis. Procedia - Social and Behavioral Sciences, 121, 291-303.

Miles, M. B., \& Huberman, A. M. (1994). Qualitative Data Analysis: An Expanded Sourcebook. London : Sage Publications.

Minichiello, V., Aroni, R., Timewell, E., \& Alexander, L. (1990). In-Depth Interviewing : Researching People. Melbourne: Longman Cheshire

Mohsin, A., Ramli, N., \& Alkhulayfi, B. A. (2016). Halal tourism: Emerging opportunities. Tourism Management Perspectives, 19, 137-143.
Nakyinsige, K., Man, Y. B. C., \& Sazili, A. Q. (2012). Halal authenticity issues in meat and meat products. Meat Science, 91(3), 207-214.

Pramintasari, T. R., \& Fatmawati, I. (2017). Pengaruh Keyakinan Religius, Peran Sertifikasi Halal, Paparan Informasi, dan Alasan Kesehatan Terhadap Kesadaran Masyarakat Pada Produk Makanan Halal. Jurnal Manajemen Bisnis, 8(1), 1-33.

Samori, Z., Md Salleh, N. Z., \& Khalid, M. M. (2016). Current trends on Halal tourism: Cases on selected Asian countries. Tourism Management Perspectives, 19, 131-136.

Strauss, A., \& Corbin, J. M. (1998). Basics of Qualitative Research: Grounded Theory Procedures and Techniques (2 ed.). California, USA: Sage Publications, Inc.

Talib, M. S. A., \& Johan, M. R. M. (2012). Issues in Halal Packaging: A Conceptual Paper. International Business and Management, 5(2), 9494.

Yin, R. K. (2011). Qualitative Research From Start to Finish. New York: The Guilford Press.

Zannierah Syed Marzuki, S., Hall, C. M., \& Ballantine, P. W. (2012). Restaurant managers' perspectives on halal certification. Journal of Islamic Marketing, 3(1), 47-58.

Zulfakar, M. H., Anuar, M. M., \& Talib, M. S. A. (2014). Conceptual Framework on Halal Food Supply Chain Integrity Enhancement. Procedia - Social and Behavioral Sciences, 121, 58-67. 